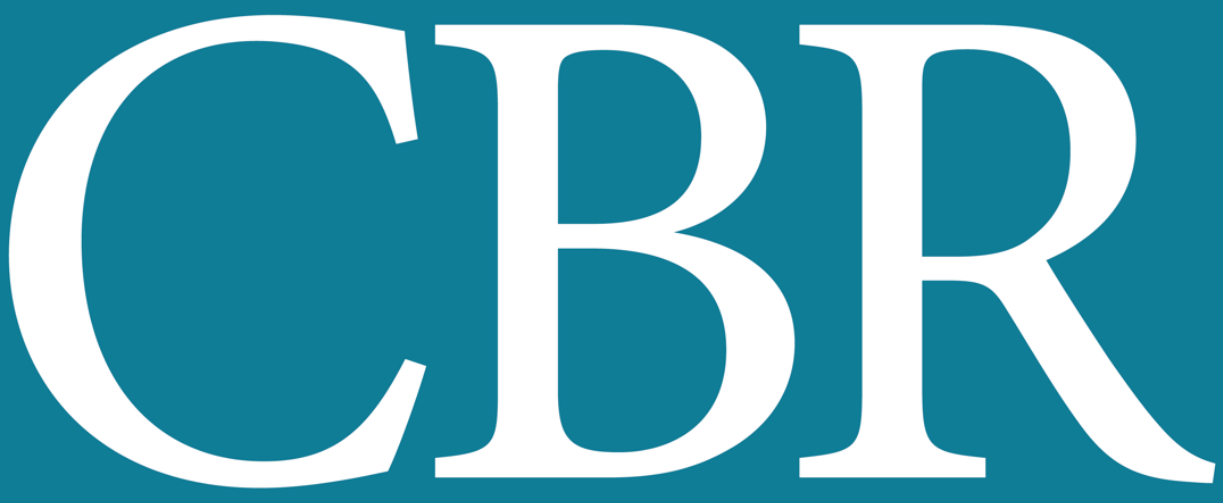

INTERNATIONAL JOURNAL OF CANCER AND BIOMEDICAL RESEARCH

https://jcbr.journals.ekb.eg

Editor-in-chief

Prof. Mohamed Labib Salem, PhD

Protective efficiency of parsley (Petroselinum crispum) against oxidative stress, DNA damage and nephrotoxicity induced with antituberculosis drugs

Mahmoud Ashry, Ismail Atia, Fatma A. Morsy and Weal Elmashad 


\section{Welcome letter from Editor-in-Chief}

Welcome to the Int J Cancer and Biomedical Research (IJCBR)!

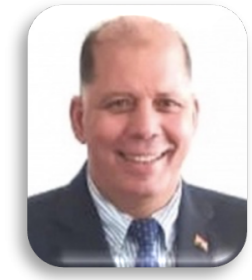

It is with great pleasure that I write this editorial to welcome you to the IJCBR. This journal provides a platform for publication of original and reviews research articles, short communications, letter to editor, thesis abstract, conference report, and case studies. These types of publication are directed at the interface of the fields of cancer and biomedical research.

The IJCBR relies on a distinguished expert of the Advisory and Editorial Board Members from the top international league covering in depth the related topics. They timely review all manuscripts and maintain highest standards of quality and scientific methodology and ethical concepts. Meanwhile, we take all possible means to keep the time of the publication process as short as possible.

I take this chance to welcome your contributions to the IJCBR and have every expectation that it will soon become one of the most respected journals in both the fields of cancer and biomedical research.

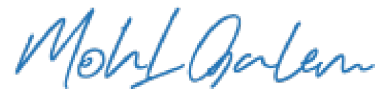

Mohamed L. Salem,

Editor in Chief 


\title{
Protective efficiency of parsley (Petroselinum crispum) against oxidative stress, DNA damage and nephrotoxicity induced with anti- tuberculosis drugs
}

\author{
Mahmoud Ashry ${ }^{1}$, Ismail Atia ${ }^{1}$, Fatma A. Morsy ${ }^{2}$ and Weal Elmashad ${ }^{3}$ \\ ${ }^{1}$ Zoology department, Faculty of Science, Al-Azhar University, Assuit, Egypt \\ ${ }^{2}$ Pathology Department, National Research Centre, Egypt \\ ${ }^{3}$ Physiology department, Faculty of Medicine, Tanta University, Egypt
}

\section{ABSTRACT}

\section{ARTICLE INFO}

Background: Tuberculosis has been seen worldwide as a serious disease, one of the most adverse side effects of main anti-tuberculosis drugs is nephrotoxicity. Aim: the purpose of this research was planned To investigate the nephroprotective ability of aqueous parsley extract against Isoniazid ${ }^{\circledR}$ and Rifampicin ${ }^{\oplus}$-induced nephrotoxicity. Materials and Methods: Adult male Wistar albino rats weighted (140-160) and they were divided randomly into four groups: 1) normal rats as a control group, 2) rats administrated with parsley extract $(250 \mathrm{mg} / \mathrm{kg} /$ day $), 3)$ rats received Isoniazid ${ }^{\circledR}$ and Rifampicin ${ }^{\circledast}(50 \& 100 \mathrm{mg} / \mathrm{kg} /$ day $)$, and 4$)$ rats treated with Isoniazid $^{\circledR}$ and Rifampicin ${ }^{\circledR}$ In association with the extract of parsley. Results: The results showed, after six weeks, that parsley extract minimized the Isoniazid ${ }^{\circledR}$ and Rifampicin $^{\circledR}$ induced renal deterioration; This was shown by a significant decrease in serum levels of urea, creatinine, uric acid, TNF- $\alpha$, IL-1 $\beta$ and Na+ as well as kidney MDA, nitric oxide and DNA damages. This was coupled with a significant improvement in serum calcium and $\mathrm{K}+$ levels and kidney GSH and SOD activity. In addition, the histopathological results indicated that the extract succeeded in the prevention of Isoniazid ${ }^{\circledR}$ and Rifampicin ${ }^{\circledR}$ induced tissue degenerations. Conclusion: In conclusion, parsley extract may be as promising as nephroprotection against Isoniazid ${ }^{\circledR}$ and Rifampicin ${ }^{\circledast}$ nephrotoxicity through their antioxidant and radical scavenging activities.

Keywords: Nephrotoxicity, Isoniazid ${ }^{\circledR}$, Rifampicin ${ }^{\circledR}$, DNA fragmentation, Parsley, rats

Editor-in-Chief: Prof. M.L. Salem, PhD - Article DOI: 10.21608/jcbr.2020.45551.1077

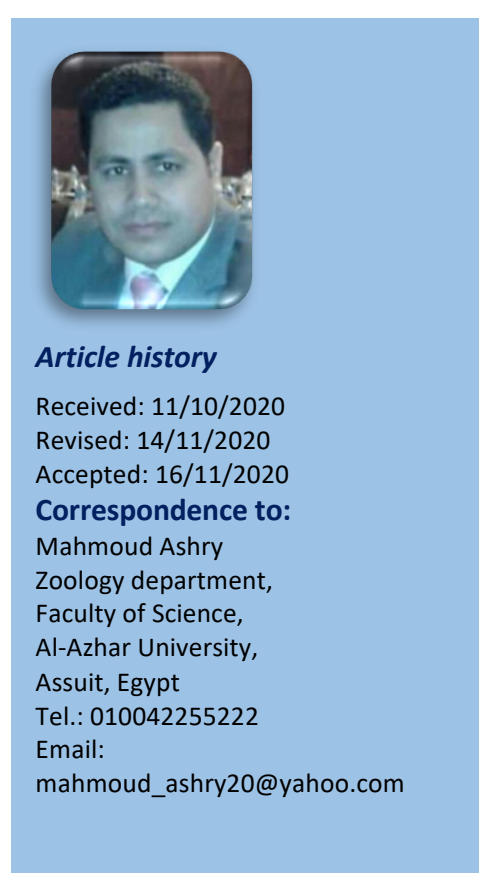

\section{INTRODUCTION}

The number one cause of death between curable contagious diseases is tuberculosis (TB), with 1.7 million persons dying of TB by 2004. As a normal treatment for adult respiratory tuberculosis infection, a 2-month regimen of anti-bactrial isoniazid, rifampicin and pyrazinamide with a 4-month regimen of isoniazid and rifampicin has been prescribed (Upadhyay and Thakker, 2017). Acute renal failure is a clinical condition characterised by a severe decrease in the ability of the kidneys to remove waste materials, perturbation of acidbase equilibrium, homeostasis of water, and a rapid decrease in the glomerular filtration rate (Prince et al., 2019).
Including blood pressure regulation, the kidney performs many excretory and regulatory functions, maintains the extracellular environment and excretes drugs (Ferguson and Walkar, 2012). Because of repeating exposure to different chemicals that can lead to deposition in the kidney inducing failure to the function of the kidney, The kidney is very sensitive to injury. Drugs are known to cause mitochondrial kidney damage that could contribute to the highly concentrated production of reactive oxygen (ROS) and reactive nitrogen (RNS) species, resulting in oxidative and nitrosative lipid, protein and DNA damage in the kidneys (Muzika et al., 2016). 
Nephrotoxicity is the most common complication of many therapeutic drugs; over the last 20 years, Increases in mortality and morbidity among patients have been documented in cases of acute renal injury (Muzika et al., 2016). Isoniazid ${ }^{\circledR}$, Rifampicin ${ }^{\circledR}$ and Pyrazinamide ${ }^{\circledR}$ 2-month regimen followed by Isoniazid ${ }^{\circledR}$ and Rifampicin ${ }^{\circledR}$ 4-month regimen is the approved routine treatment for adult respiratory TB. Isoniazid ${ }^{\circledR}(\mathrm{INH})$ is a large, semisynthetic macrocyclic lipid-soluble antibiotic formulated from Streptomyces mediterranei. It is an early drug used primarily for the treatment of all types of tuberculosis in association with rifampicin, ethambutol and pyrazinamide for the prevention of all tuberculosis forms caused by organisms with known or suspected susceptibility to tuberculosis, since it has efficacy against fastdividing organisms (early bactericidal activity) and against semi-sleeping bacterial populations, it has therefore been used in $c$ (Verma et al., 2015). Rifampicin ${ }^{\circledR}$ and Isoniazid ${ }^{\circledR}$ Anti-tuberculosis regimens containing antiretroviral regimens as co-therapy, for the treatment of human immunodeficiency virus and tuberculosis co-infection. (Pozniak et al., 2011). Since rifampicin and Isoniazid ${ }^{\circledR}$ are individually associated with downstream renal damage to renal antioxidants. Co-therapy with these medications will synergistically decrease the amount of kidney antioxidants that can have significant consequences.

Latest studies have shown that animals treated with anti-tuberculosis drugs have a clear association between nephrotoxicity and oxidative stress (Sahu et al., 2020). Since nephrotoxic effects have been demonstrated in all drugs used to treat tuberculosis, studies have been conducted to avoid or mitigate toxicity through the use of natural herbal products and/or synthetic compounds, , without interference with the clinical activities of the medication. In many studies, Natural antioxidants from different aromatic and medicinal plants have been directly associated with the reduction of chronic diseases such as DNA damage, mutagenesis and carcinogenesis. Research into alternative active antioxidant compounds, like plant extracts and essential oils, which are potentially less detrimental to the health and environment of mammals, is also of growing interest (Zhang et al., 2006). Parsley is an essential herb that comes from the Mediterranean region (Petroselinum crispum). In the dairy, pharmaceutical, perfume and cosmetics industries, Parsley belongs to the Umbelliferae family.

The parsley, however has tiny and dark seeds with a volatile glycoside fruit oil content known as apiininin (Lopez, 1999). It has been documented that Parsley has a range of potential medicinal traits, including antimicrobial traits (Wong and Kitts, 2006), antianemic agents, menorrhagic agents (Baytop 1984), anticoagulants, antihyperlipidemic agents, antihepatotoxic agents (Ozturk et al. 1991), antioxidants (Nielsen et al. 1999) and laxative agents (Nielsen et al. 1999) (Kerydiyyeh et al., 2001). It was used to regulate blood pressure for the treatment of lumbago, eczema, knee, ache, impotence, and nose bleeding (Manderfeld et al., 1997). Parsley seeds are also used as a diuretic and Ozsoy et al. (2006) have shown the hypoglycaemic role of parsley; parsley components including ascorbic acid, carotenoids, flavonoids, coumarins, apioles, various terpenoic compounds, phenylpropanoids, phathalides, furan coumarins and tocopherol (Tunali et al., 1999). The primary aim of this research was to study the antioxidant, the anti-inflammatory and ameliorative efficacy of aqueous extract of Parsley leaves against renal degradation arising from treatment with anti-tuberculosis drugs.

\section{MATERIALS AND METHODS \\ Preparation of parsley aqueous extract}

Parsley (Petroselinum crispum) leaves were collected from a local supplier store that sells supplies of spices (Abd El-Rahman Harraz, Bab El-Khalk, Cairo, Egypt), described and authenticated by botanists at Al-Azhar University Department of Botany, Faculty of Science; It was determined that the plant had a taxonomic serial number 32677. Parsley aqueous extract (PAE) was obtained from dry herb leaves according to the method defined by Gulcin et al. (2006); $100 \mathrm{~g}$ of powdered leaves were soaked at $8{ }^{\circ} \mathrm{C}$ in $400 \mathrm{ml}$ of distilled water for 24 hours, then filtered (Whatman No.1) and lyophilized using freeze drier (Snijders 
Scientific-Tilburg, Holland, pressure, 0.1 to 0.5 $\mathrm{m}$ bar and temperature $35-4^{\circ} \mathrm{C}$ ). The dry yield was measured and stored at $-20^{\circ} \mathrm{C}$ before operation.

\section{Total phenolic content (TPC)}

The complete herbal extract phenolic content was calculated as catechin equivalents (CE) using the Jayaprakasha et al. (2000) method; 5 $\mathrm{mg}$ of each residue was mixed into a $10 \mathrm{ml} \mathrm{(6:4}$ $\mathrm{v} / \mathrm{v}$ ) mixture of acetone/water; then After 30 minutes at room temperature, In combination with $1.0 \mathrm{ml}$ of Folin-Ciocalteu (10 times diluted) and $0.8 \mathrm{ml}$ of sodium carbonate solution (7.5\%), $0.2 \mathrm{ml}$ of solution $(50 \% \mathrm{w} / \mathrm{v}$ ) was measured at $765 \mathrm{~nm}$ using the UV-160 1PC UV-visible spectrophotometer, then the total phenolic content as cat solution (7.5\%)

\section{Determination of Radical Scavenging Activity (RSA) by 1, 1-diphenyl-2-picrylhydrazyl (DPPH•)}

In order to report the Nogala-Kalucka et al. (2005) process, The ability of antioxidants to quench the radical DPPH was measured and determined in accordance with the following equation. In this step, to define a concentration of $200 \mathrm{ppm}$, some of the crude extraction was dissolved in methanol; then $4 \mathrm{ml}$ of methanol was added to $0.2 \mathrm{ml}$ of this solution and $1 \mathrm{ml}$ of $\mathrm{DPPH} \bullet(6.09 \times 10-5 \mathrm{~mol} / \mathrm{L})$ solution was then added to the same solvent. After $10 \mathrm{~min}$ at $516 \mathrm{~nm}$, the absorbance was assessed against the reference blank, which was $1 \mathrm{ml}$ of DPPH solution and $4 \mathrm{ml}$ of methanol.

$$
\begin{aligned}
& \text { RSA (\%) } \\
& =\left(\frac{\mathrm{A}_{\text {control sample }}-\mathrm{A}_{\text {sample extract }}}{\mathrm{A}_{\text {control sample }}}\right) * 100
\end{aligned}
$$

\section{Experimental Design and Animals}

The National Research Centre, Cairo, Egypt, Animal Facility has obtained adult male Wistar whighted albino rats (140-160g). Before beginning the experiment, The animals were put in the required polyethylene cages for acclimatisation for one week. Meladco Company, El-Obour Region, Cairo, Egypt, has always provided fresh water and regular rodent food pellets [ $20.3 \%$ protein, $5 \%$ corn oil, $5 \%$ fibres, $3.7 \%$ salt mixture, and $1 \%$ vitamin mixture. All animals received human treatment as cited by the animal ethics committee number of the National Research Centre FWA000147477 in compliance with normal institutional standards For the treatment of laboratory animals and their use. The animals were randomly divided after acclimatisation into four classes (10 animals each as follows: 1 ) rats were orally ingested via stomach tube with saline $(0.4 \mathrm{ml} / \mathrm{kg} /$ day $)$ and act as a control, 2) rats were ingested with PAE $(250 \mathrm{mg} / \mathrm{kg} /$ day $)$ via stomach tube (Pourush et al. 2011), 3) rats were ingested with Isoniazid ${ }^{\circledR}$ and Rifampicin ${ }^{\circledR}$ (50 $\& 100 \mathrm{mg} / \mathrm{kg} /$ day), and 4) rats were orally administrated with Isoniazid ${ }^{\circledR}$ and Rifampicin ${ }^{\circledR}$ (Mahmoud et al., 2015) in combination with PAE oral administration via stomach tube; all the animals received six weeks of medication.

\section{Blood and Tissue Sampling}

The animals fasted overnight at the end of an experiment time. Blood specimens were obtained from the retro-orbital plexus under anaesthesia (diethyl ether inhalation); the sera were extracted with a cooling centrifuge (IEC centra-4R, Foreign Equipment Co., USA), divided into aliquots and processed as quickly as possible at $-80^{\circ} \mathrm{C}$ before measurements. The animals were rapidly sacrificed by decapitation after blood collection, then each animal's right kidney was dissected, washed with saline, dried, rolled into a piece of aluminium foil and stored at $-80^{\circ} \mathrm{C}$ for biochemical determination and fragmentation of DNA. The left kidney was soaked in a buffer of formalin-saline (10\%), divided, stained and equipped for microscopic testing immediately.

\section{Biochemical measurements}

Serum creatinine, urea, uric acid, total calcium and albumin levels were measured spectrophotometrically using reagent kits bought from Diamond Diagnostic MDSS GmbH Schiffgraben, Germany. The serum levels of sodium and potassium were use MEDICA Easylyte $\mathrm{Na}+\mathrm{K}+$ ANALYZER (USA) and reagent kits bought from Easylyte, USA, approximate. Using ELISA (Dynatech Microplate Reader, Canada), serum TNF- $\alpha$ and IL $1 \beta$ concentrations were measured using reagent kits (SG-10057 and SG-10179) purchased from SinoGeneClon Biotech Co., Hang Zhou, China. Kidney nitric oxide (NO), reduced glutathione (GSH) and 
superoxide dismutase (SOD) values were determined using reagent kits obtained from Biodiagnostic, Dokki, Giza, Egypt .

In this process, $0.5 \mathrm{ml}$ of supernatant homogenate was added to $4.5 \mathrm{ml}$ of working reagent [0.8 $\mathrm{g}$ TBA dissolved in $100 \mathrm{ml}$ perchloric acid] (1 g kidney tissue was homogenised at 10 $\mathrm{ml}$ phosphate buffer $\mathrm{pH} 7.4$ and centrifuged at $5000 \mathrm{rpm}$ for 10 minutes) (10 perc rpm for 10 minutes). The amount of kidney lipid peroxidation end product malondialdehyde (MDA) was chemically calculated by the method stated by Ruiz-Larrea, (1994). The samplereagent mixture was left for twenty minutes in a boiling-shaking water tank, then brought to cool down at temperature and centrifuged at a rate of $\mathbf{3 0 0 0}$ for five minutes. The absorption of the clear pink supernatant, photometrically measured at $535 \mathrm{~nm}$ against the chemical agent blank $(0.5 \mathrm{ml}$ distilled water $+4.5 \mathrm{ml}$ working reagent of TBA), directly. The amount of MDA in the $\mathrm{nmol} / \mathrm{g}$ tissue was measured.

\section{DNA fragmentation}

Fragmentation of DNA The quantity was determined by centrifugation, Differentiating the broken DNA from the intact chromatin and measuring the volume of DNA in the supernatant and pellet according to the quantitative method of Perandone (1993). The degree of DNA fragmentation in both the supernatant and the pellet refers to the ratio of DNA to the total DNA in the supernatant. In 0.5 $\mathrm{ml}$ of hypotonic lysis buffer $(10 \mathrm{mM}$ Tris- $\mathrm{HCl}(\mathrm{pH}$ 8), 1 mM EDTA and 0.2 percent Triton X-100), kidney tissue was lysed and coolly centrifuged at 14,000 ?? $\mathrm{g}$ for $20 \mathrm{~min}$ at $4 \mathrm{C}$. The pellets were re-suspended in the hypotonic lyses buffer. $0.5 \mathrm{ml}$ TCA (10\%) was applied to the resuspended pellets and the supernatants. The specimens were coolly centrifuged at 10,000 ?? g for $20 \mathrm{~min}$ and the pellets were suspended in $500 \mu \mathrm{l}$ of TCA (5 percent). A double-volume solution of diphenylamine (DPA) [200 mg DPA in $10 \mathrm{ml}$ glacial acetic acid, $150 \mu \mathrm{l}$ sulfuric acid and $60 \mu \mathrm{l}$ acetaldehyde] was subsequently treated in each sample and incubated for $48 \mathrm{~h}$ at $4{ }^{\circ} \mathrm{C}$. The fragmented DNA proportion was determined using the equation below from the absorbance reading at $578 \mathrm{~nm}$.

$$
\frac{\text { DNA fragmentation } \%=}{\frac{\text { A supernatant }}{\text { A supernatantA supernatant+A pellets }}} * 100
$$

\section{Histopathology}

The kidneys that were immersed in formalinsaline (10\%) buffer were processed and tested by optical microscope as 5um thick paraffin sections that were coated with hematoxyline and eosin (Drury, 1980).

\section{Statistical analysis}

The data obtained were analysed using the ANOVA one-way test followed by the post-hoc test (Tukey) at $p \leq 0.05$ using software programme statistical analysis system (SAS); copyright (c) 1998 by SAS Institute Inc., Cary, NC, USA.

\section{RESULTS}

Results from three in vitro estimation replicates showed that PAE possesses high yield and TPC values, and exhibits great RSA (Figure 1).

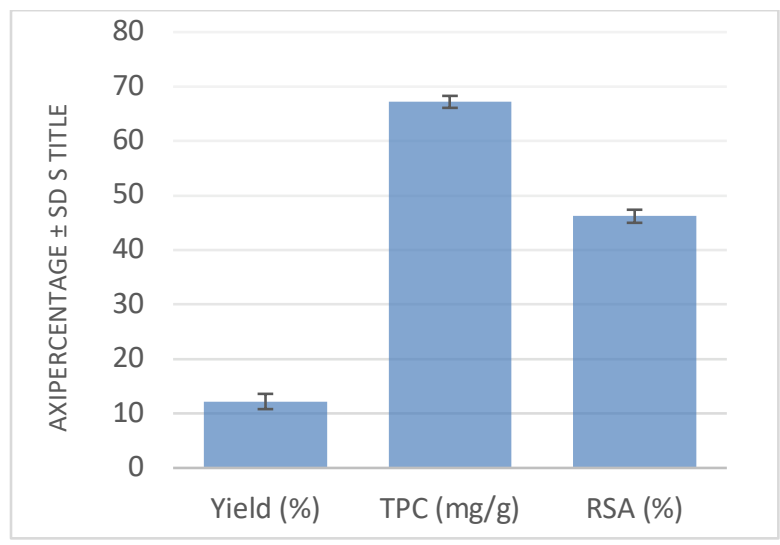

Figure 1. Mean values (of three replicates) of the yield (g /100 crude herb), radical scavenging activity (RSA) (\%) and total phenolic content (TPC) (mg/g extract) of parsley aqueous extract (PAE).

There were no adverse changes in serum creatinine, urea, uric acid and albumin levels in the animals treated with PAE relative to the control group, whereas those treated with Isoniazid and Rifampicin ${ }^{\circledR}$ showed a substantial increase in serum creatinine, urea and uric acid, along with a marked decrease in serum albumin. Interestingly, animals that were treated with PAE in combination with Isoniazid ${ }^{\circledR}$ and Rifampicin ${ }^{\circledR}$ showed a marked improvement in the mentioned measurements compare to those of Isoniazid ${ }^{\circledR} /$ Rifampicin $^{\circledR}$ treated ones (Table 1). 
Table 1. Serum creatinine, urea uric acid, albumin levels of treated and control rats.

\begin{tabular}{lllll}
\hline Groups & $\begin{array}{l}\text { Creatinine } \\
(\mathrm{mg} / \mathrm{dl})\end{array}$ & $\begin{array}{l}\text { Urea } \\
(\mathrm{mg} / \mathrm{dl})\end{array}$ & $\begin{array}{l}\text { Uric acid } \\
(\mathrm{mg} / \mathrm{dl})\end{array}$ & $\begin{array}{l}\text { Albumin } \\
(\mathrm{g} / \mathrm{dl})\end{array}$ \\
\hline Control & $1.64 \pm 0.07^{\mathrm{a}}$ & $43.9 \pm 1.5^{\mathrm{b}}$ & $5.9 \pm 0.5^{\mathrm{c}}$ & $3.7 \pm 0.11^{\mathrm{a}}$ \\
PAE & $1.59 \pm 0.09^{\mathrm{a}}$ & $44.4 \pm 1.8^{\mathrm{b}}$ & $5.7 \pm 0.9^{\mathrm{c}}$ & $3.6 \pm 0.07^{\mathrm{a}}$ \\
ATB & $3.12 \pm 0.06^{\mathrm{b}}$ & $98.5 \pm 2.1^{\mathrm{a}}$ & $8.7 \pm 0.6^{\mathrm{a}}$ & $2.8 \pm 0.07^{\mathrm{c}}$ \\
ATB+PAE & $1.90 \pm 0.05^{\mathrm{a}}$ & $52.7 \pm 2.3^{\mathrm{b}}$ & $6.4 \pm 0.7^{\mathrm{b}}$ & $3.3 \pm 0.08^{\mathrm{b}}$ \\
\hline
\end{tabular}

Data are presented as mean \pm standard error; data were subjected to one-way ANOVA followed by post hoc (Tukey) at $p \leq 0.05$. Within each column, means with different superscript letters are significantly different; PAE is parsley aqueous extract, ATB is anti-tuberculosis.

Table 2 declared that PAE never disturbs the level of serum total Calcium, Sodium or Potassium, while administration of ATB drug (INH/RIF) resulted in a significant elevation of $\mathrm{Na}+$ matched with a slight reduction in both total Calcium and $\mathrm{K}+$ levels compared with those of the control group. Favorably, administration of rats with PAE in line with ATB drug (INH/RIF) led to a markable downregulation of serum $\mathrm{Na}+$ level with a marked up-regulation of total Calcium and $\mathrm{K}+$ levels.

Table 2. Total Calcium, Sodium and Potassium levels of both treated and control rats.

\begin{tabular}{llll}
\hline Groups & $\begin{array}{l}\text { Total Calcium } \\
(\mathrm{mg} / \mathrm{dl})\end{array}$ & $\begin{array}{l}\text { Sodium } \\
(\mathrm{mmol} / \mathrm{l})\end{array}$ & $\begin{array}{l}\text { Potassium } \\
(\mathrm{mmol} / \mathrm{l})\end{array}$ \\
\hline Control & $9.51 \pm 0.66^{\mathrm{a}}$ & $152 \pm 1.32^{\mathrm{a}}$ & $6.61 \pm 0.32^{\mathrm{b}}$ \\
PAE & $9.48 \pm 0.81^{\mathrm{a}}$ & $151 \pm 1.91^{\mathrm{a}}$ & $6.41 \pm 0.21^{\mathrm{b}}$ \\
ATB & $7.18 \pm 0.39^{\mathrm{c}}$ & $178 \pm 1.56^{\mathrm{b}}$ & $4.14 \pm 0.42^{\mathrm{a}}$ \\
ATB+PAE & $8.81 \pm 1.19^{\mathrm{b}}$ & $157 \pm 1.62^{\mathrm{a}}$ & $5.81 \pm 0.62^{\mathrm{c}}$ \\
\hline
\end{tabular}

Data were assumed to be mean \pm standard error; data were subjected to single-way ANOVA followed by post hoc (Tukey) at p 0.05. Means with separate superscript letters are significantly different within each column; PAE is aqueous extract of parsley, ATB is antituberculosis.

Regarding the results of the renal oxidative status, Table 3 reveals that administration of PAE neither adverse the renal oxidative force Microscopic analysis of control sections or PAE cured rat kidneys showed a normal histological structure of renal tubules and glomerulus (Figures 4 \& 5), whereas vacuolar degeneration
(MDA and NO) nor deteriorate the antioxidative battery (GSH and SOD); however, INH/RIF-treatment resulted in a significant rise in renal MDA and NO levels associated with severe exhaustion of renal GSH and inactivation of SOD. In a promising manner, coadministration of PAE with INH/RIF resulted in a marked increase in kidney oxidative status as a result of a substantial decrease in MDA and NO concentrations, and the marked elevation of $\mathrm{GSH}$ and SOD values.

Table 3. Mean values of renal MDA, NO and GSH (reduced glutathione) levels as well as SOD activity of treated and control rats.

\begin{tabular}{lllll}
\hline Groups & $\begin{array}{l}\text { NO } \\
(\mu \mathrm{mol} / \mathrm{g} \\
\text { Tissue })\end{array}$ & $\begin{array}{l}\text { MDA } \\
(\mu \mathrm{mol} / \mathrm{g} \\
\text { Tissue })\end{array}$ & $\begin{array}{l}\text { GSH } \\
(\mathrm{mg} / \mathrm{g} \\
\text { Tissue })\end{array}$ & $\begin{array}{l}\text { SOD } \\
(\mathrm{U} / \mathrm{g} \\
\text { Tissue })\end{array}$ \\
\hline Control & $28.8 \pm 4.1^{\mathrm{c}}$ & $390 \pm 36^{\mathrm{c}}$ & $61.31 \pm 0.65^{\mathrm{a}}$ & $2220 \pm 65^{\mathrm{b}}$ \\
PAE & $27.7 \pm 3.9^{\mathrm{c}}$ & $386 \pm 28^{\mathrm{d}}$ & $62.78 \pm 0.89^{\mathrm{a}}$ & $2181 \pm 43^{\mathrm{b}}$ \\
ATB & $50.5 \pm 5.1^{\mathrm{a}}$ & $792 \pm 92^{\mathrm{a}}$ & $31.14 \pm 0.91^{\mathrm{c}}$ & $1171 \pm 85^{\mathrm{c}}$ \\
ATB+RAE & $35.4 \pm 3.2^{\mathrm{b}}$ & $487 \pm 32^{\mathrm{b}}$ & $53.93 \pm 0.77^{\mathrm{b}}$ & $2011 \pm 34^{\mathrm{a}}$ \\
\hline
\end{tabular}

Data are presented as mean \pm standard error; data were subjected to one-way ANOVA followed by post hoc (Tukey) at $p \leq 0.05$. Within each column, means with different superscript letters are significantly different; PAE is parsley aqueous extract, ATB is anti-tuberculosis,

Similarly, ingestion of ATB drug (INH/RIF) resulted in a substantial elevation in the serum TNF $\alpha$ and IL1 $\beta$ levels, while PAE administration didn't deteriorate their levels in comparison to control group; however, treatment of rats with PAE besides to INH/RIF succeeded significantly to restore the level of both cytokines close to that of the control group (Figure 2).

DNA fragmentation percentage results announced that PAE performed safe effect on DNA, while INH/RIF ingestion damaged DNA, this was achieved from the remarkable rise in its fragmentation percent when both groups were compared with the corresponding value of control one. Fortunately, co-administration of rats with PAE and INH/RIF resulted in a substantial decrease in the percentage of DNA fragmentation similar to that of regulation (Figure 3).

in most renal tubules, hyaline cast in the lumen of most tubules, and haemorrhage in either interstitial tissue or/and glomeruli were seen in kidney sections of rat groups treated with ATB 
drug (Figure 6). Favorably, rats treated with PAE along with ATB drug revealed marked renal improvements represented in minimal glomerular lobulation and Decrease of other symptoms of degeneration with enough urinary space and few haemorrhages of interstitial tissue (Figure 7).

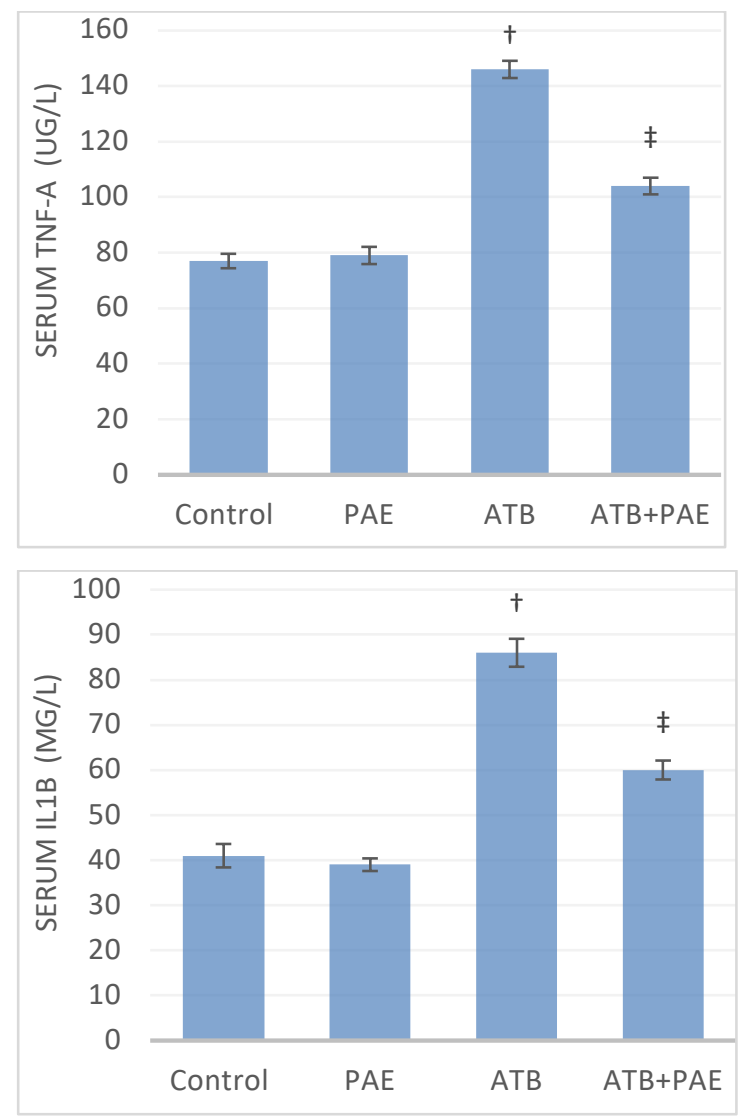

Figure 2. Serum TNF $\alpha$ and IL1 $\beta$ levels of treated animal groups; Data are presented as mean \pm standard error; $(\boldsymbol{t})$ significant $(p \leq 0.05)$ from the control group, while $(\ddagger)$ is significant $(p \leq 0.05)$ from ATB group.

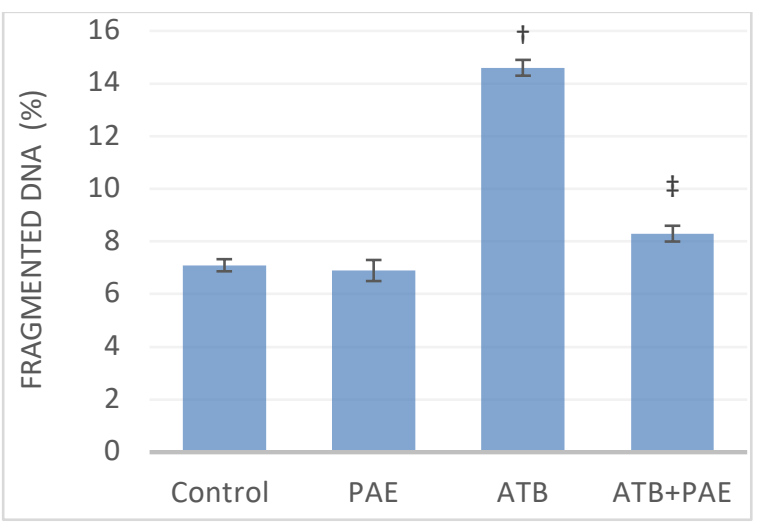

Figure 3. DNA fragmentation (\%) of treated animal groups; Data are presented as mean \pm standard error; $(\boldsymbol{t})$ is significant from the control group, while $(\ddagger)$ is significant from ATB group.

\section{DISCUSSION}

Kidney injury is a severe problem that can survive treatment and cause irreversible harm to the kidneys, nephropathy is a major complicated anti-tuberculosis therapy microvascular problem (Rekha et al., 2005); however, renal damage caused by antituberculosis therapy is typically reversible and can be treated accordingly (Rekha et al., 2005). Oxidative stress and inflammation have been shown to lead to drug-induced kidney toxicity in many studies. (Mahmoud, 2014). Therefore, the use of antioxidants could protect against oxidative stress caused by anti-tuberculosis and renal degradation. The aim of this research was to test the hypothesis that parsley aqueous extract may have prevented renal damage or malfunction in rats caused by INH/RIF by attenuating inflammation and blocking oxidative stress. The results revealed that ATB (INH/RIF) led to renal damage which was monitored from the marked rise in the serum levels of creatinine, urea and uric acid indicating impaired renal function; these parameters are also regarded as effective markers of renal damage or failure (Martin and Sabina, 2016 \& Christensen et al., 2013). Serum albumin level was fallen as a consequence to ATB indicating its loss from the blood due to damaged nephron function.

The marked drop in GSH level and SOD activity associated with a notable elevation in the renal MDA and NO levels after ATB administration reflects the reduction of the renal antioxidant battery; thereby reduces kidneys' ability to counter the effects of the toxin. These results are similar to recent studies by Prince et al. (2019) and Sahu et al. (2020), which verified their findings by renal histological changes such as glomerular tuft atrophy and infiltration of inflammatory cells and finally dysplastic renal tubules. PAE administration was successful in protecting the kidney from ATB drug toxicity as it significantly improved renal function and histological structure close to the normal pattern. The antioxidant profile of the kidneys is reversed by PAE. 


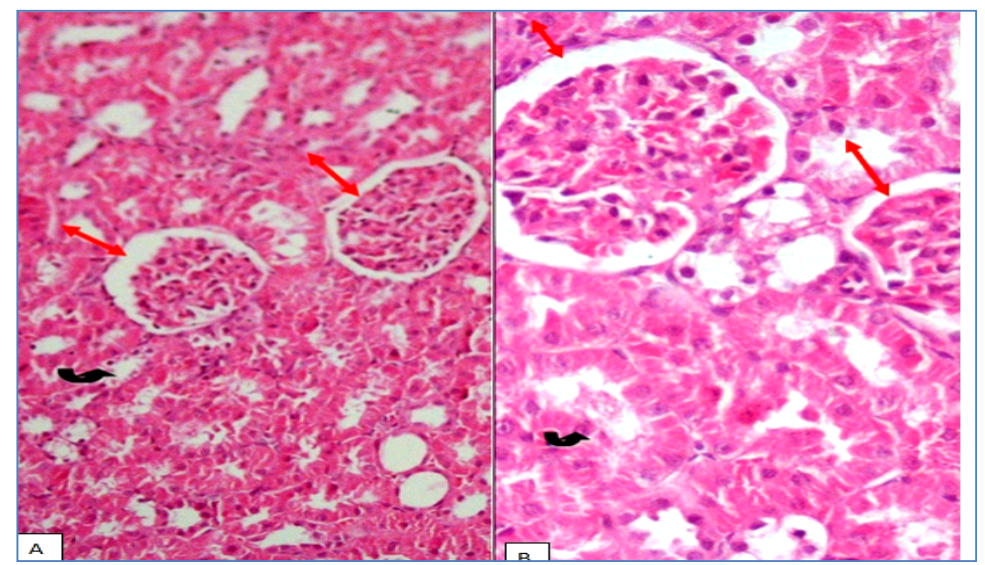

Figure 4. Section of the kidney of a control rat showing normal appearance of glomerulus and renal tubules (A). High power field showing the normal appearance of glomerulus and renal tubules (B) (Hx\&Ex400).
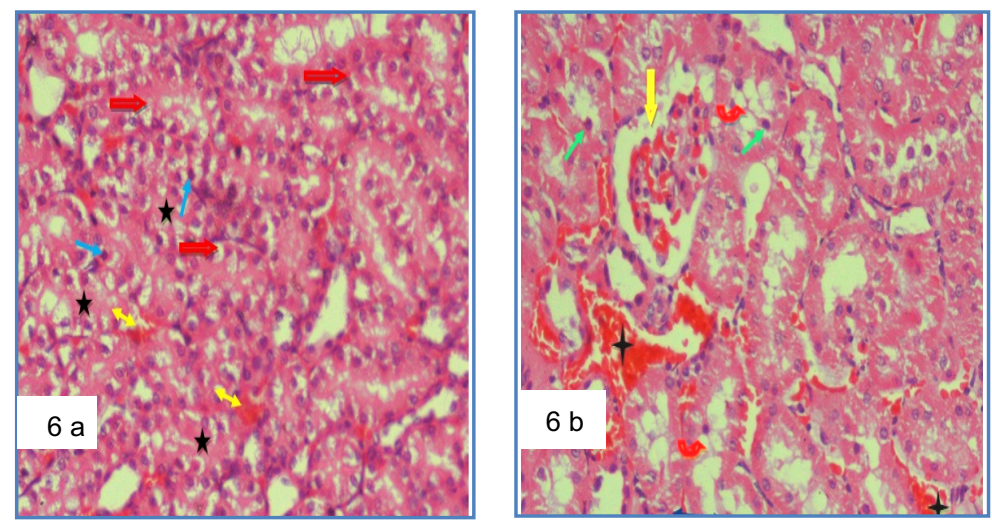

Figure 6. Section of the kidney of a rat treated with ATB only showing a vacuolar degeneration in most of the renal tubules (red arrow), hyaline cast in lumen of most tubules (star), hemorrhage (yellow arrow) in interstitial tissue (A). Another filed (B) showing degeneration of glomeruli (yellow arrow), inter-glomerular and interstitial tissue hemorrhage (star), and cellular infiltration (black arrow). Vacuolar degeneration in some tubular epithelial cells (red arrow) and pyknosis in some tubular cells (green light arrow) (Hx\&Ex400).

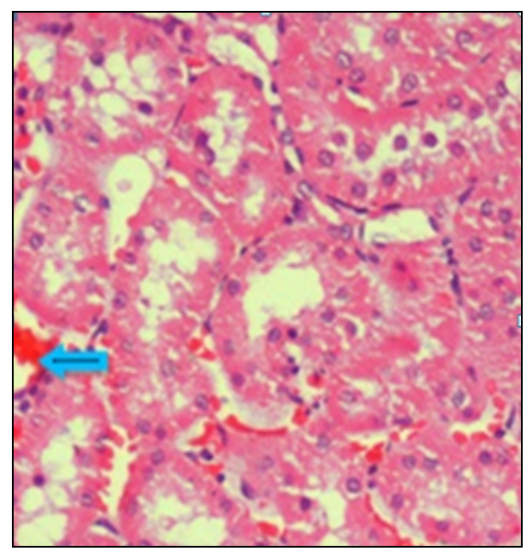

Figure 5. Section of the kidney of a rat treated with PAE only for six weeks, showing normal appearance of renal tubules and glomeruli. (HX\&EX400).

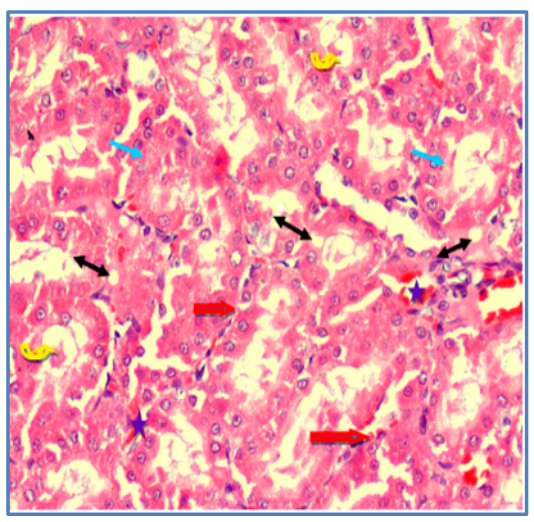

Figure 7. Section of the kidney of a rat treated with ATB along with parsley showing interstitial hemorrhage (star), cellular infiltration (red arrow) and cell debris in the lumen of some tubules (yellow curved arrow).Vacuolar degeneration (black arrow) (Hx\&Ex400).
It was suggested to inhibit lipid peroxidation and scavenge hydroxide and superoxide radicals, thus improving the antioxidant battery, the active constituents present in PAE such as flavonoids and vitamin C. In this context, the protective role of PAE may be due to the antiperoxidant and antioxidant effects of its components. These findings are in line with the latest reports (Al-Seeni et al., 2018 \& Elkomy et al., 2020.)

In addition, the current study pointed out that the administration of ATB resulted in a substantial increase in the serum level of inflammatory cytokines (TNF alpha \& IL-1 $\beta$ ) as well as the percentage of DNA fragmentation; this finding is agonised by recent data from Wali et al. (2020) and Shabbir et al (2020). TNF alpha and IL-1 $\beta$ are active pro-inflammatory cytokines and are significant mediators of damage to inflammatory tissue. Among the drug-induced nephrotoxicity mechanisms, the immune system has been included; several previous studies showed evidence that nephrontoxicants could induce inflammatory responses leading to organ injury (Martin and Sabina, 2016). The pathogenesis of drug-induced kidney damage has been implicated in ROS and oxidative stress (Lopez-Novoa et al., 2011. With regards to the structure of renal lipids, longchain polyunsaturated fatty acids are easy to obtain and this makes the kidney at risk of acute 
damage caused by ROS (Ozbek, 2012). Furthermore, ROS can cause lipid peroxidation, cellular protein damage, DNA fragmentation and alter the antioxidant defence mechanism (Nencini et al., 2007). Renal DNA has been reported to be attacked by free radicals produced by ATB drugs, as evidenced by higher levels of kidney damage and DNA damage (Alkreathy et al., 2014.

In this study, PAE efficiently down-regulated serum levels of the tested inflammatory cytokines (IL-1 $\beta$ and TNF- $\alpha$ ), enhanced antioxidant activities and restored the histopathological changes of the kidney. These results suggest that PAE possesses antiinflammatory and immune-modulatory characteristics may be mechanized through its antioxidant components; in vitro results showed that PAE performed high phenolic content and radical scavenging activity confirming its antioxidant activities as stated previously by Kooti et al. (2017). SOD plays a key role in protecting the body from the harmful effects of ROS (Wei et al., 2011). INH administration was reported to produce a significant increase in MDA and NO and a substantial decrease in antioxidant defences in rats (Mahmoud, 2014). Therefore, we assume that PAE's nephro-protective mechanism against oxidative stress induced by INH/RIF is comparable to being mediated by GSH restoration and enzymatic antioxidant defence potentiation. In line with the results of the biochemical assessment, histopathological findings demonstrated that PAE administration exhibited ameliorative capacity against ATB induced renal injury; this could be mechanized through the antioxidant, anti-inflammatory, and immune-modulatory activity of PAE components.

\section{CONCLUSION}

In conclusion, the findings of the current research indicate that PAE may emerge as a putative nephro-protective, alleviates DNA fragmentation and membrane-stabilizing effects against nephrotoxicity initiated by antituberculosis drugs. In order to validate these results and their extrapolation to humans, further research must be carried out.

\section{CONFLICT OF INTEREST}

Authors declare that they have no conflicts of interest.

\section{FUDING}

There is no financial support for this study.

\section{REFERENCES}

Alkreathy HM, Khan RA, Khan MR, Sahreen S. CCl4 induced genotoxicity and DNA oxidative damages in rats: hepatoprotective effect of Sonchus arvensis. BMC Complementary and Alternative Medicine 2014; 14: 452.

Al-Seeni MN, El Rabey HA, Al-Ghamdi H, Al-Sieni Al, Sakran MI and Mohammed GM. Assessment of the antioxidant activity of parsley and carob in hypercholesterolemic male rats. Biomedical Research 2018; 29 (17): 3370-3377.

Baytop T. Therapy with Medicinal Plants in Turkey (Past and Present), Istanbul University Yayinlari, 1984; 3255.

Christensen El, Nielsen R, Birn H. From bowelto kidneys: The role of cubilin in physiologyand disease. Nephrology Dialysis Transplantation. 2013; 28:274-281.

Drury RAB, Wallington EA. Preparation and fixation of tissues. In: Drury RAB, Wallington EA, editors. Carleton's Histological Technique. 5. Oxford: Oxford University Press 1980; pp. 41-54.

Elkomy A, Aboubakr M, Medhat Y, Abugomaa A and Elbadawy M. Nephroprotective Effects of Cinnamon and/or Parsley Oils against Gentamicin-Induced Nephrotoxicity in Rats. Journal of Animal and Veterinary Advances 2020; 19 (1): 8-14.

Ferguson MA and Walkar SS. Established and Emerging Markers of Renal Function. Clinical Chemistry 2012; 58; 4:680-689.

Jayaprakasha GK and Rao L. "Phenolic constituents from lichen parmotrema stuppeum(NYI.) Hale and their antioxidant activity. Zeitschrift fur Naturforschung.C" Journa of Bioscience, 2000; 55.N.11-12.1018-1022.

Kerydiyyeh SI, Uste J, Kaouk I, Al-Sadi R. The mechanism underlying the laxative properties of parsley extract. Phytomedicine 2001; 8: 382388.

Kooti, Wesam; DARAEI, Nahid. A review of the antioxidant activity of celery (Apium graveolens L). Journal of Evidence-based Complementary \& Alternative Medicine, 2017; 22 (4): 10291034.

Lopez MG, Sancheze-Medoza IR, Ochoa-Alejo N. Comparative study of volatile components and fatty acids of plants and in vitro cultures of 
parsley (Petroselinum crispum) (Mill) nymex hill). Journal of agricultural and food chemistry1999; 47: 3292-3296.

Lopez-Novoa JM, Quiros Y, Vicente L, et al. New insights into the mechanism of aminoglycoside nephrotoxicity: an integrative point of view. Kidney international 2011; 79: 33-45.

Mahmoud AM, Morsy BM, Abdel-Hady DS and Samy RM. Prunus rmeniaca Leaves Extract Protects against Isoniazid and Rifampicin Induced Nephrotoxicity through Modulation of Oxidative stress and Inflammation. International Journal of Food and Nutritional Science 2015; 2(2):100-105.

Mahmoud, A.M. Hesperidin protects against cyclophosphamide-induced hepatotoxicity by up regulation of PPARY and abrogation of oxidative stress and inflammation. Canadian Journal of Physiology and Pharmacology 2014; 92(9): 717-724.

Manderfeld MM, Schafer HW, Davidson PM, Zottola EA. Solation and identification of antimicrobial furocoum-arins from parsley. Journal of food protection 1997; 60: 72-77.

Martin SJ and Sabina EP. Amelioration of antituberculosis drug induced oxidative stress in kidneys by Spirulina fusiformis in a rat model. Renal Failure 2016; 38: 1115-1121.

Muzika V, Čustović S, Mornjaković Z, Ćosović E and Kapić D. Histological study of isoniazidrifampicin related nephrotoxicity in Wistar rats. Folia Medica Facultatis Medicinae Universitatis Saraeviensis 2016; 51(1): 4-9.

Nencini C, Giorgi G, Micheli L. Protective effect of silymarin on oxidative stress in rat brain. Phytomedicine 2007; 14(2-3): 129-135.

Nielsen SE, Young JF, Daneshvar B, Lauridsen ST, Knuthsen $P$, Sandstrom B. Effect of parsley intake on urinary apigenin excretion, blood antioxidant enzymes and biomarkers for oxidative stress in human subjects. British Journal of Nutrition 1999; 81: 447-455.

Nogala-Kalucka M, Korczak J, Dratwia M, Lampartszczapa E, Siger A, Buchowski M. Changes in antioxidant activity and free radical scavenging potential of rosemary extract and tocopherols in isolated rapeseed oil triacylglycerols during accelerated tests. Food Chemistry 2005; 93, pp.227-235.

Ozbek E. Induction of oxidative stress in kidney. International journal of nephrology 2012.

Ozsoy-Sacan O, Yanardag R, Orak H, Ozgey Y, Yarat A, Tunali T. Effects of parsley (Petroselinum crispum) extract versus glibornuride on the liver of streptozotocininduced diabetic rats. Journal of ethnopharmacology 2006; 104 (1-2): 175181.
Ozturk Y, Baser CHK, Aydin S. Hepatoprotective ntihepatotoxic) plants in Turkey. Proceedings of the $9^{\text {th }}$ Symposium on Plant Drugs, Eskisehir, Turkey, May, 1991: 40-50.

Perandones CE, Illera VA, Peckham D, Stunz LL, Ashman RF. Regulation of apoptosis in vitro in mature murine spleen $T$ cells. The Journal of Immunology 1993; 151(7): 3521-9.

Pourush B, Rajendra MB, Diya V and Pradeep KC. Hypolipidemic activity of Petroselinum cripsum plant in triton WR-1339 induced rat. Herbal Tech. Industry 2011; 1:101-141.

Pozniak AL, Coyne KM, Miller RF, Lipman MC, Freedman AF and Ormerod LP. HIV British HIV Association guidelines for the treatment of TB/ HIV coinfection. HIV Medicine 2011; 12: 517524

Prince SE, Martin SJ, Lavinya BU, Selvanathan K, Geetha A. Anti-tuberculosis drug-induced oxidative stress in kidneys: Role of brahmi as an antioxidant supplement. Pharmacognosy Magazine 2019; 15: 12-6.

Rekha, V. V. B., Santha, T., Jawahar, M. S. Rifampicin induced renal toxicity during retreatment of patients with pulmonary tuberculosis. Journal of the Associations of Physicians of India 2005; 53: 811-813.

Ruiz-Larnea MB, Leal AM, Liza M, Lacort M, de Groot $H$. Antioxidant effects of estradiol and 2 hydroxyestradiol on iron induced lipid peroxidation of rat liver microsome. Steriod 1994; 59: 383-388.

Sahu N, Mishra G, Chandra HK, Nirala SK and Bhadauria $M$. Naringenin mitigates antituberculosis drugs induced hepatic and renal injury in rats. Journal of Traditional and Complementary Medicine 2020; 10: 26-35.

Shabbir M, Afsar T, Razak S, Almajwal A and Khan MR. Phytochemical analysis and Evaluation of hepatoprotective effect of Maytenus royleanus leaves extract against antituberculosis drug induced liver injury in mice. Lipids in Health and Disease 2020; 19:46.

Tunali T, Yarat A, Yanardag R, Ozcelik F, Ozsoy O, Ergenekon G, Mekli N E. Effect of parsley (Petroselinum crispum) on the skin of STZ induced diabetic rats. Pharmacological and Toxicological Evaluation of Natural Product Derivatives 1999; 13: 138-141.

Upadhyay GP and Thakker RM. Utility of pleural fluid routine and microscopy examination plus adenosine deaminase levels in the diagnosis of tuberculous pleural effusion. International Journal of Medical Science and Public Health. 2017; 6: 11.

Verma AK, Yadav A, Dewangan J, Singh SV, Mishra M, Singh PK, Rath SK. Isoniazid prevents Nrf2 
ranslocation by inhibiting ERK1phosphorylation and induces oxidative stress and apoptosis. Redox Biology 2015; 6: 80-92.

Wali AF, Pillai JR, Al Dhaheri Y, Rehman MU, Shoaib A, Sarheed O, Jabnoun S, Razmpoor M, Rasool S, Paray BA and Ahmad P. Crocus sativus L. Extract Containing Polyphenols Modulates Oxidative Stress and Inflammatory Response against Anti-Tuberculosis Drugs-Induced Liver Injury. Plants 2020; 9: 167.

Wei XJ, Hu TJ, Chen JR, et al. Inhibitory effect of carboxymethyl pachymaran on cyclophosphamide-induced oxidative stress in mice. International journal of biological macromolecules 2011; 49(4): 801-805.

Wong PYY and Kitts DD. Studies on the dual antioxidant and antibacterial properties of parsley (Petroselinum crispum) and cilantro (Coriandrum sativum) extracts. Food Chemistry 2006; 97: 505-515.

Zhang, H., et al., Evaluation of antioxidant activity of parsley (Petroselinum crispum) essential oil and identification of its antioxidant constituents. Food Research International 2006; 39(8): 833839. 


\section{Egyptian Association for Cancer Research (EACR)}

http://eacr.tanta.edu.eg/

EACR is an NGO society that was declared by the Ministry of Social Solidarity (Egypt) No. 1938 in 19/11/2014 based on the initiative of Prof. Mohamed Labib Salem, the current Chairman of EACR. EACR aims primarily to assist researchers, in particular young researchers in the field of cancer research through workshops, seminars and conferences. Its first international annual conference entitled "Anti-Cancer Drug Discovery" was successfully organized in April 2019 (http://acdd.tanta.edu.eg). Additionally, EACR aims to raise the awareness of the society about the importance of scientific research in the field of cancer research in prediction, early diagnosis and treatment of cancer. EACR is also keen to outreach the scientific community with periodicals and news on cancer research including peer-reviewed scientific journals for the publication of cutting-edge research. The official scientific journal of EACR is "International Journal of Cancer and biomedical Research (IJCBR: https://jcbr.journals.ekb.eg) was successfully issued in 2017 and has been sponsored by the Egyptian Knowledge Bank (EKB: www.ekb.eg).

\section{EACR Chairman,}

Prof. Mohamed Labib Salem, PhD

Professor of Immunology

Faculty of Science, Tanta Universiy, Egypt 
International Journal of Cancer and Biomedical Research (IJCBR), a publication of the Egyptian Association for Cancer Research (EACR), is a peer-reviewed online journal published quarterly. The journal allows free access (Open Access) to its contents and permits authors to self-archive a final accepted version of the articles on any OAl-compliant institutional / subject-based repository.

\section{Aim And Scope}

Aim: The main aim of IJCBR is to attract the best research in animal and human biology in health and diseases from across the spectrum of the biomedical sciences at the molecular, cellular, organ, and whole animal levels especially those that are related to cancer research, including causes, prediction, diagnosis, prognosis and therapy.

Scope: It is essential reading for all researchers interested in biochemistry, cancer, microbiology, nutrition, physiology, genetics, immunology, epidemiology, medical economics, human biology, bioinformatics, biotechnology, nanotechnology, and disease modeling.

\section{Publication Ethics}

Researchers should conduct their research from research proposal to publication in line with the best practices and codes of conduct of relevant professional bodies and/or national and international regulatory bodies. IJCBR accepts manuscripts prepared in accordance with the "Uniform Requirements for Submission of Manuscripts for Biomedical Journals adopted by the International Committee of Medical Journal Editors (ICMJE) and the Committee on Publication Ethics (COPE). Details of ICMJE and COPE are available at http://www.icmje.org/ and http://publicationethics.org/

\section{Peer Review Process}

After the IJCBR editor receives a manuscript, the first step is to confirm that the manuscript meets the journal's rules for content and format, including similarity check (plagiarism) which should be less than $25 \%$. If the manuscript meets the journal's rules, the editor then assign it to the double-blind peer review process. The IJCBR editor send the manuscript to at least two experts in the field for RIGOROUS scientific evaluation. The experts called peer reviewers - will then prepare a report that assesses the manuscript and return it to the editor through the IJCBR portal. Upon the first submission, this reviewing process takes about 4 to 6 weeks. After reading the peer reviewer's report, the editor will decide one of the following four options:

1. Reject the manuscript.

2. Accept the manuscript

3. Ask the authors to revise and resubmit the manuscript after responding to the peer reviewers' feedback.

4. Ask for peer-review from additional reviewers.

If the authors resubmit the manuscript, the IJCBR editor will ask the same peer-reviewers to look over the manuscript again to confirm that their concerns have been addressed. This is called re-review process. This second revision (if applicable) takes about another 4 to 6 weeks. At this point, the abstract of the article appears in press. The online publication (the PDF format) of the final version of the manuscript takes from 2 to 4 weeks. As such, the total publication cycle takes from 2 to 4 months. This cycle can be reduced to 4 to 6 weeks (fast track publication) for the manuscripts with outstanding findings.

The peer-review process used by IJCBR includes comments on errors in the study's methods or analysis that raise questions about the findings, or sections that need clearer explanations. The peer-review process also includes the importance and novelty of the manuscript and its interest to the journal's audience. The IJCBR uses double-blind review, which means that both the reviewers and authors identities are concealed from the reviewers, and vice versa, throughout the review process. To facilitate this, authors need to submit a Title Page containing the Authors details and Blinded Manuscript with no author details as 2 separate files. 


\section{Publisher}

The International Journal of Cancer and Biomedical Research (IJCBR) is an International and interdisciplinary journal of preclinical and clinical studies in the area of cancer and biomedical research. It is a peer-reviewed journal in English, published quarterly (in March, June, September, and December) by the Egyptian Association for Cancer Research (EACR) in both print and online formats (4 issues making a volume). Special issues or supplements may also be produced from time to time upon agreement with the Editorial Board.

\section{Scope}

The main aim of IJCBR is to attract the best research in animal and human biology in health and diseases from across the spectrum of the biomedical sciences at the molecular, cellular, organ, and whole animal levels especially those that are related to cancer research, including causes, prediction, diagnosis, prognosis and therapy.

\section{Publication Fees}

The journal does charge for submission, processing or publication of manuscripts (2000 LE for Egyptians or $\$ 300$ for non-Egyptians; EACR members receive 15\% discount on publication). Of them Peer-review fees (300 LE) should be paid on submission (non-refundable). For the fast track production of the accepted manuscript, another $500 \mathrm{LE}$ is paid.

General specifications for different types of article

- Submitted manuscripts should not have been published previously, except in a limited form (e.g. short communication to a symposium or as part of MSc or PhD theses) and should not be under consideration for publication by other journals.

- All co-authors should agree with the content of the manuscript. Authors must have obtained permission to use any copyrighted material in the manuscript before submission.

\section{IJCBR publishes different types of articles}

- Original Article (6000 words with $\mathbf{4}$ tables and $\mathbf{4}$ figures, maximum $\mathbf{8}$ display items): Articles with novel findings are the target of IJCBR. Articles presenting a detailed description of a new technique, comparison of existing methods, meta-analyses with comprehensive and in-depth discussion are considered. Papers in a numbered series are not accepted unless all are submitted at the same time.

- Short communications or case study (3000 words with 4 display items): Short communications present exceptionally exciting, novel or timely contents are considered. They will be peer-reviewed in the same way as research papers. The references are restricted to 15 .

- Reviews or systematic review (9000 words with $\mathbf{1 0}$ display items): They are invited by the Editorial Board or unsolicited. Review articles have to be contemporary and comprehensive and add information to the knowledge. Sharp critical analyses of novel data or concepts are encouraged. When relevant, a statistical analysis of data and a meta-analysis approach are recommended.

- Opinion papers, letter to the editor or comment to the editor (1500 words with $\mathbf{2}$ display items): They are submitted by invitation of the Editorial Board. They are short papers, which aim to inform scientists, industry, and the public and policymakers about cutting-edge issues in research or the impact of research. They reflect the opinion of their authors who bear full responsibility of the published paper. The references are restricted to 10 .

- Conference/Symposium papers: The journal will consider for publication the results of original work and critical reviews that are presented at conferences/symposia. Symposium organizers who wish to publish bundles of papers from a symposium/conference in IJCBR should first contact the Editor-inChief of the IJCBR (EACR@unv.tanta.edu.eg) for agreement. Supplementary material can be proposed and will be made available online. The responsibility for the preparation of a paper in a form suitable for publication lies with the author.

- Thesis: IJCBR can publish the summary and abstract of Master and PhD theses in a special issue. 
English: Good quality of written English is required. Spelling may be in British or American English but must be consistent throughout the paper. Care should be exercised in the use of biological terminology that is ill-defined or of local familiarity only. We recommend that authors have their manuscripts checked by an English language native speaker before submission.

Manuscript layout: Manuscripts should be prepared using a standard word processing program and presented in a clear readable format with easily identified sections and headings. The manuscript layout is based on the following directions.

- The main text contains Title, Abstract, Keywords, Introduction, Material and Methods, Results, Discussion, References, Tables, figures.

- The title needs to be concise and informative. Use bold, with an initial capital for the first word only and for words that ordinarily take capitals

- Short (running) title (max 80 characters including spacing).

- The article text should be typed with double-line spacing with wide margins $(2.5 \mathrm{~cm})$.

- The lines must be continuously numbered; the pages must also be numbered.

- Font Calibri 12 should be used for the text, and 12 for the tables, figure legends and references.

- The sections should typically be assembled in the following order:

- Title page contains title, authors' names, full affiliations, acknowledgements and the corresponding author's contacts and Short title.

Abstract (max 250 words, single paragraph): The abstract should be complete and understandable without citation, references, table or figure. Use structured abstract: Background, Aim, Materials \& Methods, Results and Conclusion. The context and the rationale of the study are presented succinctly to support the objectives. The experimental methods and main results are summarized but should not be overburdened by numerical values or probability values. The abstract ends with a short and clear conclusion.

Keywords: Up to five short and specific keywords should complement the title with respect to indicating the subject of the paper in alphabetic order.

Introduction: The introduction briefly outlines the context of the work, presents the current issues that the authors are addressing and the rationale to support the objectives, and clearly defines the objectives.

Material and methods: Material and methods should be described in sufficient details so that others can repeat the experiment. Reference to previously published work may be used to give methodological details, provided that said publications are readily accessible and in English. The code of ethics should be followed for all experiments use animals or human samples.

Statistical analysis of results: The statistical design and the models of statistical analysis must be described, as well as each of the statistical methods used. Sufficient statistical details must be given to allow replication of the statistical analysis. The experimental unit should be defined (e.g. individual or group of animals).

Results: Data are presented as tables and figures. Brief description of the results for each table and figure should be presented. Unpublished data can be mentioned when necessary.

Discussion: Should be separate from the Results section and should focus only on intra- and inter-data discussion (the data in the results section) as well as with the relative data in the literature. Don't repeat information already presented in the Introduction section. Start the first paragraph in the Discussion with a paragraph stating the rationale behind the study, the objectives and the main findings. End Discussion with a short conclusion.

Acknowledgements: In this section, the authors may acknowledge (briefly) their support staff.

Conflict of interest: All papers with a potential conflict of interest must include a description/explanation in a separate heading.

Funding details: The authors should state the source of findings of the study (with research funder and/or grant number). If no fund, the authors should state that the study is self-funded. 


\section{References}

Citation of references: In the text, references should be cited by the author(s) surname(s) and the year of publication (e.g. Salem, 2020). References with two authors should be cited with both surnames (e.g. Salem and Meshrif, 2021). References with three or more authors should be cited with the first author followed by et al. (in italics; e.g. Salem et al., 2021). Names of organizations used as authors (e.g. Food and Drug Administration) should be written out in full in the list of references and on the first mention in the text. Subsequent mentions may be abbreviated (e.g. FDA).

- List of references. Literature cited should be listed in alphabetical order by authors' names. It is the author's responsibility to ensure that all references are correct. All authors should be written and so the full journal name.

- References from journal articles are formatted in APA as this example: Al-Amoudi WM (2018). Toxic effects of Lambda-cyhalothrin on the rat thyroid. Involvement of oxidative stress and ameliorative effect of ginger extract. Toxicology Reports, 5: 728-736.

- References from books or official reports are formatted as this example. Kebreab E, Dijkstra ANM, Bannink A, Gerrits WJJ, \& France J (2006). Nutrient digestion and utilization in farm animals. CABI Publishing. Wallingford, UK.

- References from chapters or parts of books are formatted as this example. Nozière $P, \&$ Hoch $T$ (2006). Modelling fluxes of volatile fatty acids from rumen to portal blood. In: Nutrient digestion and utilization in farm animals (Kebreab E, Dijkstra ANM, Bannink A, Gerrits WJJ \& France J, eds.), pp. 40-47. CABI Publishing. Wallingford, UK.

Tables:

The data should be presented in tables or in graphs, not both.

- Each table should be placed on a separate page at the end of the main text.

- Tables are numbered consecutively using Arabic numbering. They are referred to as Table 1 , Table 2, etc., with capital ' $T$ ', no italics

- Each table has its explanatory caption. The caption is sufficient to permit the table to be understood without reference to the text.

- Abbreviations used in tables/figures have to be defined either as footnotes or in the caption.

Figures

- Package the figures in a single PowerPoint file. Each figure in a separate slide.

- Figure size should be readable in a width of approximately 8-175 $\mathrm{mm}$ (i.e. the maximum size of printing over two columns).

- Ensure that the font size is large enough to be readable at the final print size, use Calibri font to ensure that they are consistent throughout the figures.

- The figures should preferably be provided as TIFF or EPS files.

- The resolutions of figures must be at least $300 \mathrm{dpi}$.

- Preparation of images for a manuscript: For guidance, we refer to the Journal of Cell Biology's instructions to authors (http://jcb.rupress.org/site/misc/ifora.xhtml\#image_aquisition).

- If a cropped image is included in the main text of a paper (e.g. a few lanes of a gel), display the full original image, including the appropriate controls, the molecular size ladder and/or the scale as relevant, as a single figure in a Supplementary Material file to facilitate peer-review and for subsequent online publication.

- Supplementary material is submitted along with the main manuscript in a separate file and identified at uploading as "Supplementary File - for Online Publication Only" The title of the article is included at the top of the supplementary material.

Corresponding author's guidelines: Upon acceptance the corresponding author is required to send his/her recent formal photo to be attached to the front page of the article. 


\title{
International Journal of Cancer \& Biomedical Research
}

(IJCBR) Online ISSN 2682-2628

\author{
Editor-in-Chief \\ Mohamed Labib Salem, PhD \\ Tanta University, Egypt
}

\begin{tabular}{l} 
EACR Board \\
\hline Nehal Elmashad, MD \\
Tanta University, Egypt \\
Nabil Mohy Eldin, PhD \\
Kafrelsheikh University, Egypt \\
Doaa Al-Ghareeb, PhD \\
Alexandria University, Egypt \\
Abdel-Aziz Zidan, PhD \\
Damanhour University, Egypt
\end{tabular}

\begin{tabular}{l} 
Managing Editor \\
\hline Wesam Meshrif, PhD \\
Tanta University, Egypt \\
Sohaila Galal, PhD \\
Tanta University, Egypt \\
Production and Contact \\
\hline Hamdi Kandil \\
Tanta University, Egypt \\
Email: ljcbr100@gmail.com
\end{tabular}

\section{Advisory Board}

Alberto Montero, MD

Taussig Cancer Center, Cleveland,

USA

Yi Zhang, MD

Zhengzhou University, China

Mark Robunstein, Ph D

Medical University of South

Carolina, USA

Mohsen Farid, Ph D

Derby University, USA

Natarajan Muthusamy, Ph D

Ohio State University, USA

Hideki Kasuya, MD

Nagoya University, Japan

Sherif El-Khamisy, Ph D

Sheffield University, UK

Mohamed Ghanem, Ph D

Kafr Elshikh University, Egypt

Sayed Bakry, Ph D

Alazhar University, Egypt

Sameh Ali, Ph D

Nationa Liver Institute, Egypt

Gamal Badr, Ph D

Assuit University, Egypt

Nadia Hamdy, Pharm D

Ain Shams University, Egypt

\section{Editorial Board}

\section{Clinical studies}

Hesham Tawfik, MD

Tanta University, Egypt

Mohamed Attia, MD

Tanta University, Egypt

Mohamed Elshanshory, MD

Tanta University, Egypt

Essam Elshiekh, MD

Tanta Cancer Center, Egypt

Rasha Eraky, MD

Tanta University, Egypt

Shaima Abou-Kjatwa, MD

Tanta University, Egypt

Marcela Diaz, MD

Cleveland Clinic Foundation, USA

Mohamed Abou-El-Enein, MD

Charité Universitätsmedizin Berlin,

Germany
Alaa Eldin Almostafa, MD

McGill University, Canada

Olfat Gadallah, MD

Tanta University, Egypt

Nagla Sarhan, MD

Tanta University, Egypt

Naglaa Fathy, Pharm D

Zagazik University, Egypt

Mohamed Salama, MD

Mansoura University, Egypt

Mona Marie, MD

Alexandria University, Egypt

Preclinical studies

Mostafa El-Sheekh

Tanta University, Egypt

El-Refai Kenawy, Ph D

Tanta University, Egypt

Mohamed Noureldin, Ph D

Banaha University, Egypt

Yousry Albolkiny, Ph D

Tanta University, Egypt

Elsayed Salim, Ph D

Tanta University, Egypt

Shengdian Wang, Ph D

Chinese Academy of Sciences,

China

Sabry El Naggar, Ph D

Tnata Univesity, Egypr

Faris Alenzi, Ph D

Prince Sattam bin Abdulaziz

University, KSA

Ibrahim El-Sayed, Ph D

Menoufia University, Egypt

Tarek Aboul-Fadl, Ph D

Assiut University, Egypt

Rabab Khairat, Ph D

National Research Center,

Giza, Egypt

Wael Lotfy, Ph D

Alexandria University, Egypt

Ashraf Tabll, Ph D

National Research Center, Egypt

Nahla Shoukry, Ph D

Suez University, Egypt
Medhat Eldenary, Ph D

Tanta University, Egypt

Azza Hasan, Ph D

Menufia University, Egypt

Nanees Gamal Eldin, Ph D

Tanta University, Egypt

Mohamed Mansour, UK

Sabbah Hammoury, Ph D

Alexandria Ayadi Almostaqba

Oncology Hospital, Egypt

Nehal Aboulfotoh, Ph D

Zewail City for Science and

Technology, Cairo, Egypt

Amir Elkhami, Ph D

Galaxo, San Francisco, USA

Ahmed Alzohairy, Ph D

Zagazi University, Egypt

Wgady Khalil, Ph D

National Research Center, Egypt

Amr Amin, Ph D

United Arab Emirates

University, UAE

AbdelRahman Zekri, Ph D

National Cancer Institute, Egypt

Hussein Khamis, Ph D

Alexandria University, Egypt

Magdy Mahfouz, Ph D

Kafr Elsheikh University, Egypt

Ehab Elbedewey, Ph D

Tanta University, Egypt

Abeer Badr, Ph D

Cairo University, Egypt

Mamdooh Ghoneum, Ph D

Charles Drew University of

Medicine \& Science, USA

Haiam Abou Elela, Ph D

National Institute of Oceanography and Fisherie, Egypt

Maha EL-Demellawi, Ph D City for Scientific Research \&

Technology Applications, Egypt

Desouky Abd-El-Haleem, Ph D

City for Scientific Research \&

Technology Applications, Egypt 